\title{
Biodegradable Foams Based on Starch, Polyvinyl Alcohol, Chitosan and Sugarcane Fibers Obtained by Extrusion
}

\author{
Flávia Debiagi $^{1}$, Suzana Mali ${ }^{*}$, Maria Victória Eiras Grossmann ${ }^{2}$ and Fábio Yamashita ${ }^{2}$ \\ ${ }^{1}$ Departamento de Bioquímica e Biotecnologia; Centro de Ciências Exatas; Universidade Estadual de Londrina; C. \\ P.: 6001; 86051-990; Londrina - PR - Brasil. ${ }^{2}$ Departamento de Ciência e Tecnologia de Alimentos; Centro de \\ Ciências Agrárias; Universidade Estadual de Londrina; C. P.: 6001, 86051-990, Londrina - PR - Brasil
}

\begin{abstract}
Biodegradable foams made from cassava starch, polyvinyl alcohol (PVA), sugarcane bagasse fibers and chitosan were obtained by extrusion. The composites were prepared with formulations determined by a constrained ternary mixtures experimental design, using as variables: $\left(X_{1}\right)$ starch / PVA (100 - 70\%), $\left(X_{2}\right)$ chitosan $(0-2 \%)$ and $\left(X_{3}\right)$ fibers from sugar cane $(0-28 \%)$. The effects of varying proportions of these three components on foam properties were studied, as well the relationship between their properties and foam microstructure. The addition of starch/PVA in high proportions increased the expansion index and mechanical resistance of studied foams. Fibers addition improved the expansion and mechanical properties of the foams. There was a trend of red and yellow colors when the composites were produced with the highest proportions of fibers and chitosan, respectively. All the formulations were resistant to moisture content increase until $75 \%$ relative humidity of storage.
\end{abstract}

Key words: cassava starch, mechanical properties, microstructure and expansion

\section{INTRODUCTION}

In recent years, much progress has been achieved in the development of biodegradable products using agricultural material as basis. Various approaches have used starch for the production of different functional materials (Soykeabkaew et al., 2004). Considerable effort has been made to develop starch foams as alternative to expanded polystyrene (EPS) for loosefill packaging application. Starch foams with insulating properties that are similar to polystyrene foam have been industrially developed by extrusion. Extrusion technology is a high-temperature, shortduration process with the advantage of high versatility and absence of effluents (Bastioli et al.,
1994, 1998a; Bhatnagar and Hanna, 1995, Cha et al., 2001; Fang and Hanna, 2001; Lacourse and Altieri, 1989, 1991; Willett and Shogren, 2002; Chiellini et al., 2009).

Starch foams can be employed to substitute the polystyrene products, but it is known that thermoplastic starch composites have weak mechanical properties, such as poor water resistance (Guan and Hanna, 2004). Bio-based materials, such as cellulose, and other biodegradable polymers are being used as ingredients to improve the moisture sensitivity and mechanical properties of starch-based foams (Lawton et al., 2004; Guan and Hanna, 2006; Salgado et al., 2008; Lee et al., 2009). Some authors have also reported that the resistance of

*Author for correspondence: smali@uel.br 
starch foams to the direct contact with water showed an improvement by the addition of a high proportion of polyvinyl alcohol (Shogren et al., 1998; Shogren and Lawton, 1998). Polyvinyl alcohol (PVA) is a particularly well-suited synthetic polymer for the formulation of blends with natural polymers, as it is highly polar and can also be manipulated in water solutions, and depending upon its grade, in functional organic solvents as well (Chiellini et al., 2001).

Another biopolymer used in combination with starch to produce the biodegradable foams is chitosan, a cationic polymer produced by alkaline $\mathrm{N}$-deacetylation of chitin, which is the main component of the shells of crab, shrimp, and krill (Nakamasu et al., 2006; Wang et al., 2006). Nakamasu et al. (2006) reported that chitosan and starch could be used to produce the porous structures. According to Wang et al. (2006), chitosan/PVA foams demonstrated interconnected and open-cell structures with large pore size.

In this work, sugarcane bagasse fiber, an underutilized waste residue from sugar and alcohol industries was evaluated as filler for starch foams to reduce the moisture sensitivity. Brazil is the largest worldwide producer of ethanol from sugarcane, and large amounts of fibers is left as a by-product, which is cheap, non-toxic, easily recyclable and its use contributes to environmental protection (Ruggiero et al, 2006). During the biodegradation process, the presence of fibers induced a faster breaking in pieces of the samples due to the action of microorganism attracted by the lignocellulosic components (Chiellini et al., 2009). Thus, the objectives of this work were to evaluate the effects of cassava starch, polyvinyl alcohol, sugarcane bagasse fibers and chitosan on microstructure, density, expansion index, color, water adsorption and mechanical properties of extruded foams using a mixture design methodology.

\section{MATERIALS AND METHODS}

\section{Materials}

Cassava starch (19\% amylose) was provided by Hiraki Industry (São Paulo, Brazil). Sugarcane fiber was provided by the regional ethanol producers, which was milled and sieved through mesh N-50 obtaining a product with a size between 290 - $297 \mu \mathrm{m}$ and before use, it was dried. PVA (ACS degree, molecular weight 72,000 and degree of hydrolysis of $86.5-89.5 \%$ ) was purchased from Reagen (Quimibrás Industrias Química, Rio de Janeiro, Brazil), chitosan was obtained from Sigma Aldrich (EUA) and glycerol from Synth (Labsynth, São Paulo, Brazil).

\section{Foams production by extrusion}

A three-component constrained simplex mixture design (Cornell, 1990) was used to study the effects of cassava starch/PVA $\left(\mathrm{X}_{1}\right)$, chitosan $\left(\mathrm{X}_{2}\right)$ and fibers $\left(\mathrm{X}_{3}\right)$ on the properties of the extruded foams. The range selected for each component was based on previous experience and ranged from 70 to $100 \%$ for starch/PVA, 0 to $2 \%$ for chitosan and 0 to $28 \%$ for sugarcane fibers. The starch/PVA employed proportion was 60/40. Table 1 shows the nine employed formulations and two replications at center point in terms of its original components and pseudo-components (a set of components that took on the values from 0 to 1 over the feasible region). The pseudo-components were calculated as follows: $\mathrm{X}_{\mathrm{I}}^{\prime}=\left(\mathrm{X}_{\mathrm{i}}-\mathrm{L}_{\mathrm{i}}\right) /\left(1-\Sigma \mathrm{L}_{\mathrm{i}}\right)$, here, $X_{i}^{\prime}$ was the i'th pseudo-component, $X_{i}$ was the original component value, $L_{i}$ was the lower constraint (limit) for the i'th component, $\Sigma L_{\mathrm{i}}$ was the sum of all lower constraints (limits) for all the components in the design and this transformation made the coefficients for different factors comparable in size (Cornell, 1990).

To prepare each formulation, the indicated proportions of starch/PVA, chitosan and sugarcane fibers (Table 1), glycerol (20\% w/w) and water (sufficient to produce the samples with $18 \%$ of moisture content before extrusion) were mixed during $5 \mathrm{~min}$ at $780 \mathrm{rpm}$ (Arno - Brasil). The extrusion of the samples was performed in a single-screw extruder (BGM EL-25, São Paulo, Brasil) with a barrel (700 mm in length and $25 \mathrm{~mm}$ in diameter). Temperatures from the feeding to die zone were maintained at $120^{\circ} \mathrm{C}$ and two $2.8 \mathrm{~mm}$ die nozzles were employed to produce the cylindrical foams extrudates. The screw speed was maintained at $70 \mathrm{rpm}$. The extrudates were cut into $100 \mathrm{~mm}$ samples with a rotary cutter operating at $20 \mathrm{rpm}$. 
Table 1 - Mixture composition in extruded foams formulated with cassava starch, polyvynil alcohol (PVA), chitosan and sugarcane fibers in a three-component constrained simplex mixture design.

\begin{tabular}{|c|c|c|c|c|c|c|}
\hline \multirow{2}{*}{ Run } & \multicolumn{3}{|c|}{ Original components } & \multicolumn{3}{|c|}{ Pseudocomponents ${ }^{b}$} \\
\hline & Starch/ PVA $(\%)^{a}$ & Chitosan (\%) & Fibers (\%) & Starch/PVA $\left(\mathbf{X}^{\prime}{ }_{1}\right)$ & Chitosan $\left(\mathbf{X}^{\prime}{ }_{2}\right)$ & Fibers $\left(\mathbf{X}_{3}^{\prime}\right)$ \\
\hline 1 & 100 & 0 & 0 & 1 & 0 & 0 \\
\hline 2 & 98 & 2 & 0 & 0.933 & 0.067 & 0 \\
\hline 3 & 70 & 2 & 28 & 0 & 0.067 & 0.933 \\
\hline 4 & 72 & 0 & 28 & 0.067 & 0 & 0.933 \\
\hline 5 & 86 & 0 & 14 & 0.533 & 0 & 0.467 \\
\hline 6 & 99 & 1 & 0 & 0.967 & 0.033 & 0 \\
\hline 7 & 84 & 2 & 14 & 0.467 & 0.067 & 0.467 \\
\hline 8 & 71 & 1 & 28 & 0.033 & 0.033 & 0.933 \\
\hline 9 & 85 & 1 & 14 & 0.500 & 0.033 & 0.467 \\
\hline 10 & 85 & 1 & 14 & 0.500 & 0.033 & 0.467 \\
\hline 11 & 85 & 1 & 14 & 0.500 & 0.033 & 0.467 \\
\hline
\end{tabular}

${ }^{\mathrm{b}}-\mathrm{X}_{1}^{\prime}=(\%$ starch -0.70$) / 0.30 ; \mathrm{X}_{2}^{\prime}=(\%$ chitosan -0.00$) / 0.30$ and $\mathrm{X}_{3}^{\prime}=(\%$ fibers -0.00$) / 0.30$.

\section{Foams characterization}

Density

Density was calculated as the ratio between the weight and volume (Shogren et al., 1998). The reported values were the averages of ten determinations of each formulation.

\section{Expansion index}

The expansion index (EI) was measured dividing the extrudates diameter by die orifice diameter (Gujska and Khan, 1991). Reported values were the averages of twenty determinations of each formulation.

\section{Scanning electron microscopy (SEM)}

SEM analyses were performed with a FEI Quanta 200 microscope (Oregon, USA). Foams pieces were mounted on the bronze stubs using a doublesided tape and then coated with a layer of gold (40-50 nm), allowing surface and cross-section visualization. To obtain the cross-section, the samples were prepared by immersion into liquid nitrogen in order to avoid the deformation during the fracture. All the samples were examined using an accelerating voltage of $20 \mathrm{kV}$.

\section{Adsorption isotherms}

Starch foams specimens were pre-dried for 14 days over phosphorous pentoxide $\left(\mathrm{P}_{2} \mathrm{O}_{7}\right)$ and then were placed at $25^{\circ} \mathrm{C}$ over saturated salt solutions in separated desiccators having desired water activities $(0.11,0.32,0.43,0.58,0.75$ and 0.90$)$ (Rockland, 1960). Each foam specimen was weighed at regular intervals (minimum $6 \mathrm{~h}$ and maximum $12 \mathrm{~h}$ ), and when two consecutive weights were equal, it was assumed that an equilibrium condition was reached. Under the above conditions, an equilibrium period of seven days was sufficient to establish the moisture equilibrium in all the samples. Equilibrium moisture content was calculated from the increase in the mass of the dried sample after equilibration at a given RH. All the tests were conducted in triplicate.

\section{Color}

Foams color was determined using a colorimeter (CR 10, Minolta Chroma Co., Osaka, Japan). The color parameters range from $\mathrm{L}=0$ (black) to $\mathrm{L}=$ 100 (white), - a (greenness) to +a (redness), and -b (blueness) to $+\mathrm{b}$ (yellowness). The instrument was calibrated using a set of three Minolta calibration plates. Reported values were the averages of five determinations of each formulation.

\section{Mechanical properties}

A texture analyzer model TA.XT2i (SMS, Surrey, $\mathrm{UK}$ ) with a $25 \mathrm{~N}$ load cell was used to determine the compression strength of samples. The $10 \mathrm{~mm}$ long extrudates were placed on a flat plate with carefully aligned cut surfaces so that the edges were perpendicular to the axis of the sample (direction of extrusion). Then, each foam was compressed once to $80 \%$ of its original diameter at a loading rate of $5.0 \mathrm{~mm} / \mathrm{s}$ using a Knife probe. The force $(\mathrm{N})$ was reported as compression strength. Reported values were the averages of fifteen determinations of each formulation. 


\section{Statistical data analysis}

Experiments were design and analysed using Statistica software version 6.0 (Statsoft Oklahoma). Linear models (equation 2) for three components were fitted to the experimental data:

$Y=\beta_{1} X_{1}^{\prime}+\beta_{2} X_{2}^{\prime}+\beta_{3} X_{3}^{\prime}$

where $\mathrm{Y}$ was a predictive dependent variable; $\beta_{1}$, $\beta_{2}$ and $\beta_{3}$ were the corresponding parameter estimates for each linear term produced for the prediction models for cassava starch/PVA $\left(\mathrm{X}_{1}{ }_{1}\right)$, chitosan $\left(\mathrm{X}_{2}^{\prime}\right)$ and sugarcane fibers $\left(\mathrm{X}_{3}^{\prime}\right)$, respectively. The pseudo-components were employed to fit the models and to construct the surface contour plots.

\section{RESULTS AND DISCUSSION}

The results (Table 2) were statistically evaluated. Thecalculated regression coefficients of the equations and the analysis of variance (ANOVA) are shown in Table 3. All the models were statistically significant $(\mathrm{p} \leq 0.05)$ and able to explain $80-98 \%$ of the variation $\left(\mathrm{R}^{2}\right)$. No significant lack of fit $(\mathrm{p}>0.05)$ was observed, showing the good correlation between the models and the experimental data. The different proportions between starch/PVA $\left(\mathrm{X}^{\prime}{ }_{1}\right)$ and fibers $\left(\mathrm{X}_{3}^{\prime}\right)$ caused significant alteration in all the measurements $(\mathrm{p} \leq 0.05)$, except for $\mathrm{a}^{*}$ parameter of color, for which only the fibers proportions $\left(X_{3}\right)$ was significant. The chitosan $\left(\mathrm{X}_{2}^{\prime}\right)$ proportion was significant only for the density and $\mathrm{b}^{*}$ parameter of color (Table 3 ).

Table 2 - Experimental results of expansion index (EI), density, force $(N)$ and color parameters $\left(L^{*}, a^{*}\right.$ and $\left.b^{*}\right)$.

\begin{tabular}{ccccccc}
\hline \multirow{2}{*}{ Run } & \multicolumn{7}{c}{ Responses } & \multicolumn{3}{c}{} \\
\cline { 2 - 7 } & Density $\left(\mathbf{g} / \mathbf{c m}^{\mathbf{3}}\right)$ & $\mathbf{E I}$ & Force $\mathbf{( N )}$ & $\mathbf{L}^{*}$ & $\mathbf{a}^{*}$ & $\mathbf{b}^{*}$ \\
\hline 1 & 0.20 & 3.05 & 69 & 48.1 & 0.73 & 4.27 \\
2 & 0.22 & 2.65 & 72 & 39.2 & 1.13 & 8.93 \\
3 & 0.33 & 1.19 & 45 & 23.64 & 8.11 & 14.00 \\
4 & 0.30 & 1.41 & 57 & 29.9 & 8.64 & 11.91 \\
5 & 0.27 & 2.07 & 62 & 34.17 & 8.02 & 7.12 \\
6 & 0.25 & 2.72 & 68 & 47.12 & 1.15 & 6.93 \\
7 & 0.29 & 1.84 & 58 & 32.15 & 8.36 & 10.93 \\
8 & 0.34 & 1.39 & 49 & 27.2 & 8.39 & 12.99 \\
9 & 0.30 & 2.04 & 67 & 30.1 & 6.85 & 10.12 \\
10 & 0.29 & 1.96 & 65 & 29.2 & 7.16 & 9.99 \\
11 & 0.27 & 1.99 & 61 & 31.6 & 5.66 & 11.12 \\
\hline
\end{tabular}

Table 3 - Coefficients of the polynomial models for the response variables.

\begin{tabular}{lcccccc}
\hline Coefficients $^{\mathbf{a}, \mathbf{b}}$ & Density & EI & Force & $\mathbf{L}^{*}$ & $\mathbf{a}^{*}$ & $\mathbf{b}^{*}$ \\
\hline$\beta_{1}$ & $0.22^{* *}$ & $2.90^{* *}$ & $73^{* *}$ & $45.69^{* *}$ & 2.11 & $4.97^{* *}$ \\
$\beta_{2}$ & $0.56^{*}$ & -1.31 & 8 & -39.49 & 3.15 & $57.36^{* *}$ \\
$\beta_{3}$ & $0.32^{* *}$ & $1.32^{* *}$ & $52^{* *}$ & $26.51^{* *}$ & $10.01^{* *}$ & $11.67^{* *}$ \\
$\mathrm{p}$ (model) & 0.0003 & 0.0001 & 0.0008 & 0.0004 & 0.0021 & 0.0001 \\
$\mathrm{R}^{2}$ (model) & 0.87 & 0.98 & 0.83 & 0.90 & 0.80 & 0.94 \\
$\mathrm{P}$ (lack of f it) & 0.4829 & 0.1727 & 0.3905 & 0.1974 & 0.1614 & 0.3900 \\
\hline
\end{tabular}

${ }^{\mathrm{a}-} \beta_{1}=$ starch/PVA; $\beta_{2}=$ chitosan e $\beta_{3}=$ fibers.

b- $* *$ Significant at $5 \%(\mathrm{p} \leq 0.05)$ and $0.1 \%(\mathrm{p} \leq 0.001)$.

Density is an important physical property of extruded foams and low density is a desirable attribute for these products because of reduction in the material cost (Lee et al., 2009). In this work, density was positively influenced by the effects of starch/PVA $\left(\mathrm{X}_{1}^{\prime}\right)$, chitosan $\left(\mathrm{X}_{2}^{\prime}\right)$ and fibers $\left(\mathrm{X}_{3}^{\prime}\right)$ proportions (Table 3). When the content of these three components increased, density increased; however, the effects of chitosan and fiber proportions on the density were higher than the effect of starch/PVA (Table 3). Figure 1 shows a decreasing trend for the density with increasing of starch/PVA and decreasing of fiber proportions.This occurred because the shear generated inside the extruder barrel was not enough to form the starch-fiber network required 
for expansion. These results agreed with some data reported by other authors. According to Guan and Hanna (2004) and Salgado et al. (2008), the density of starch foams increased with the increase in fiber content. Carvalho et al. (2003) and Jin et al. (1995) reported that an increase in fiber content appeared to increase the starch chain degradation during extrusion because it caused an increase in the product temperature, extruder torque, die pressure and axial expansion of the extrudate. Thus, the increase in density could be explained due to the breakage of the starch glycosidic linkages during the extrusion to form the molecules of small molecular weight, which decreased the wall extensibility of the cells and caused the rupture of the macrostructure of the product (Lee et al., 2009). Besides, Funabashi and Kunioka (2005) found that the existence of fibers during the extrusion caused a decrease in the density due to the fiber trapping air inside the foam which increased the expansion.

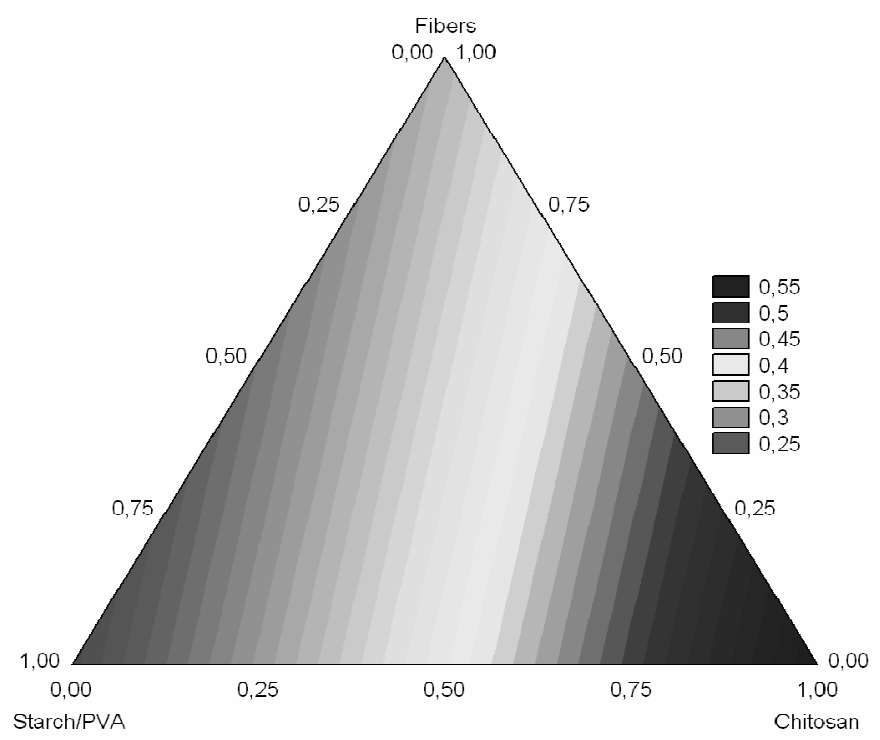

Figure 1 - Contour plot for density of biodegradable foams formulated with starch/PVA, chitosan and sugarcane fibers.

In this work, density of starch foams ranged from 0.20 to $0.34 \mathrm{~g} / \mathrm{cm}^{3}$ (Table 2), which was higher than the values of expanded polystyrene, close to $0.06 \mathrm{~g} / \mathrm{cm}^{3}$ (Glenn et al., 2001; Shey et al., 2006). They were also higher than the values $(0.067$ to $0.106 \mathrm{~g} / \mathrm{cm}^{3}$ ) reported by other authors for the foams made with high amylose starch (Miladinov and Hanna, 2001) and high amylose maize starch, which ranged from 0.048 to $0.091 \mathrm{~g} / \mathrm{cm}^{3}$ (Guan and Hanna, 1994). However, these values were lower than those reported by Salgado et al. (2008) for the foams made of cassava starch, cellulose fibers, and sunflower protein isolate, which ranged from 0.456 to $0.587 \mathrm{~g} / \mathrm{cm}^{3}$. Tartaka and Cunninghan (1998) attributed the higher density of starch-based foams compared to the expanded polystyrene ones to the open cells of starch foams, which prevented the material from continuing to expand.
EI is an important property to define the foam production cost. In general, extruded foams with lower densities have higher EI (Rhee et al., 1999; $\mathrm{Xu}$ et al., 2005). The EI of starch foams was influenced positively by the linear effects of starch/PVA $\left(\mathrm{X}_{1}^{\prime}\right)$ and fibers $\left(\mathrm{X}_{3}^{\prime}\right)$ proportions. The starch/PVA effect was more important for the increase of this property (Table 3 ). Figure 2 shows the increase of EI with the increase in starch/PVA proportion and decrease in fiber and chitosan proportions. The lowest EI value (Table 2) were obtained for the formulations produced with the maximum of fiber $(28 \%)$ and chitosan $(2 \%)$ proportions, and a proportion of starch/PVA of $70 \%$ (run 3 of the experimental design - Table 1). These results agreed with the density values discussed above and could be explained as the same way. Besides, according to other authors 
(Carr et al., 2006; Cinelli et al., 2006), some vegetable fibers act as a reinforcing material only at low concentration levels, and the increase in fiber content results in the foams with higher densities and lower EI. The presence of fibers in the foam formulation is responsible for an increase in the viscosity of this mixture, which causes a less expandable material, a smaller average cell size, a thicker cell wall, and higher density (Shogren and Lawton, 1998).

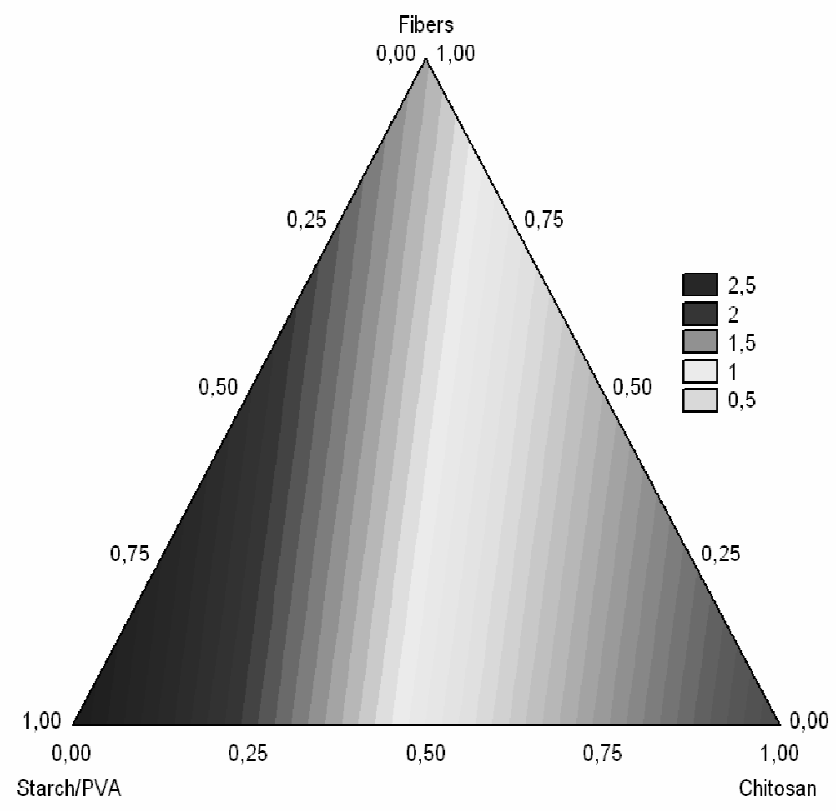

Figure 2 - Contour plot for expansion index of biodegradable foams formulated with starch/PVA, chitosan and sugarcane fibers.

Figure 3 shows some SEM micrographs of the produced foams. Foams produced exclusively with starch/PVA (run 1 of experimental design - Table 1) resulted in a material with good expansion, which was observed by the opened cell structure when compared to the foams produced with low starch/PVA (70\%) and high chitosan (2\%) and fiber (28\%) proportions, as run 3 of experimental design (Table 1), which showed closed cell structure. Fiber accumulation was observed (arrow
1), resulting in a non-homogeneous structure (Fig. 3), as also reported by Carr et al. (2006), who related this non-homogeneity to a decrease in the compression strength of the foams, as discussed below. According to others researchers (Moraru and Kokini, 2003; Preechawong et al., 2004), the opened cell structure of foams was a result of the venting of large amount of water molecules when the starchy polymer emerged from the extruder die.

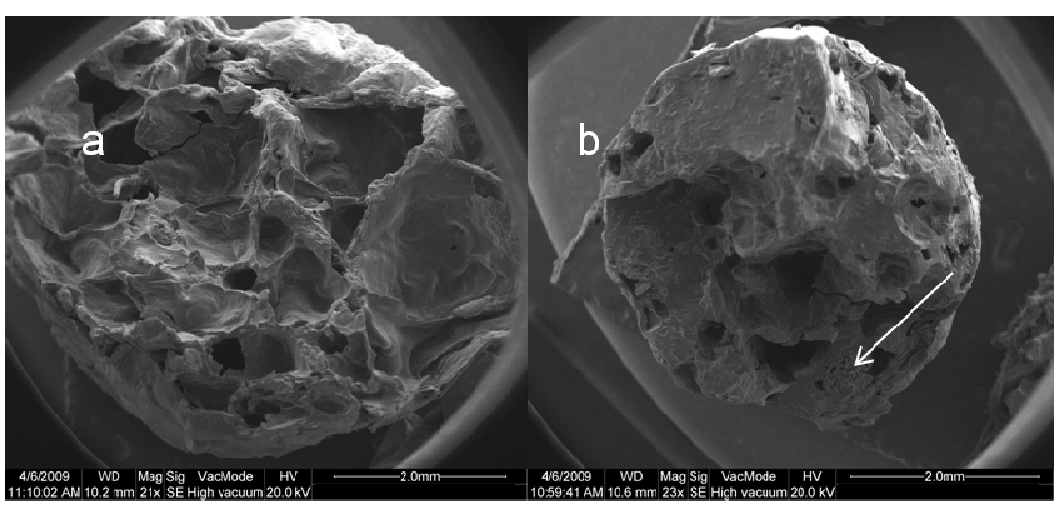

Figure 3 - Scanning electron micrographs of biodegradable foams formulated as follows: (a) $100 \%$ starch/PVA and (b) $70 \%$ starch/PVA, $2 \%$ chitosan and $28 \%$ fibers. 
The effect of starch/PVA on homogeneity and expansion of produced foams could be explained by the high compatibility between the starch and PVA, which contributed to the formation of less rigid and more expandable foam matrices with less starch-starch interaction, resulting in the materials with good expansion properties (Cinelli et al., 2006; Lui and Peng, 2005).

Starch/PVA $\left(\mathrm{X}_{1}^{\prime}\right)$ and sugarcane fibers $\left(\mathrm{X}_{3}^{\prime}\right)$ positively affected the compression strength (force) of the samples (Table 3). The starch/PVA effect, however, was more significant (Table 3), as higher values were obtained at higher starch/PVA proportions (Fig. 4). According to Cinelli et al. (2006), the addition of PVA to starch foams led to the formation of structures which were more resistant (less rigid) to compression, possibly due to the break of hydrogen bonds of starch and the PVA content in the foam formulation. According to Carr et al. (2006), starch foams had their compression strength improved by the fiber addition until its content reached around $15 \%$. The foams containing around $30 \%$ fibers had lower strength, probably due to uneven fiber distribution. Lee et al. (2009) reported that the presence of fibers resulted in good bonding with the starch matrix which can form a stronger matrix, thereby increasing the compressive strength of the foam. Lawton and Shogren (2002) found that the addition of $5-10 \%$ fiber clearly produced higher strength foams because the fibers adhered well to the starch matrix, and thus acted as reinforcement. This could be observed in this work; the foams with the highest fibers proportions had their compression strength decreased (Table 2) compared with those formulated with the intermediary levels, probably because of the formation of a non-homogeneous structure, as observed by SEM (Fig. 2).

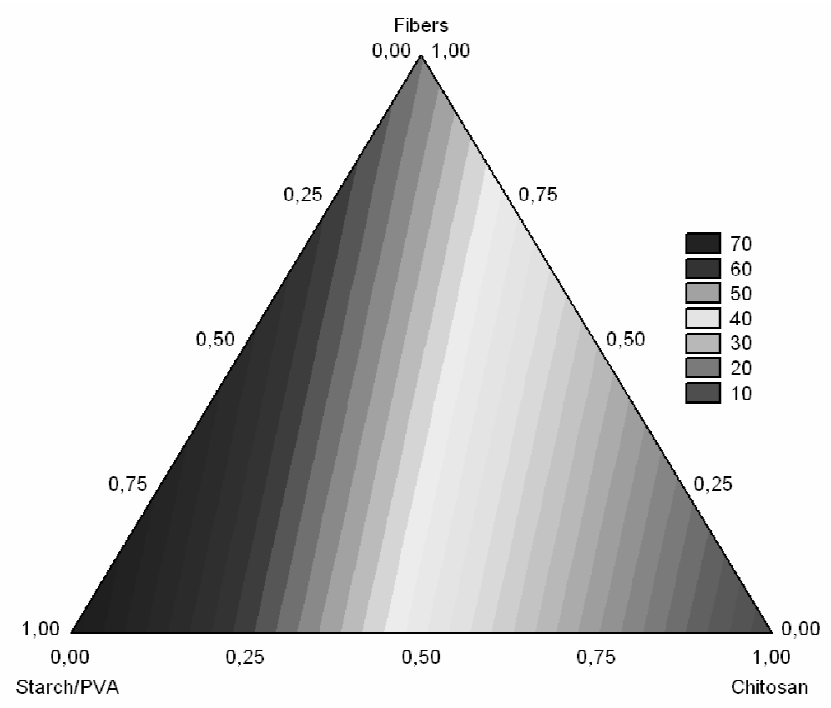

Figure 4 - Contour plot for force of biodegradable foams formulated with starch/PVA, chitosan and sugarcane fibers.

The color parameters of the foams are shown in Table 2. Luminosity ( $\left.\mathrm{L}^{*}\right)$ was positively influenced by the linear effects of starch/PVA $\left(\mathrm{X}_{1}^{\prime}\right)$ and sugarcane fibres $\left(\mathrm{X}_{3}^{\prime}\right)$; the effect of starch/PVA on L* (Table 3) was higher than the effects of the other components (Table 3). Figure 5 a showed that the luminosity increased with increasing starch/PVA content in the studied experimental region.

According to ANOVA (Table 3), parameter $\mathrm{b}^{*}$ was influenced bythe linear effects of starch/PVA $\left(\mathrm{X}_{1}^{\prime}\right)$, chitosan $\left(\mathrm{X}_{2}^{\prime}\right)$ and sugarcane fibers $\left(\mathrm{X}_{3}^{\prime}\right)$ proportions, but the most important effect was exerted by chitosan addition (Table 3 ). Figure $5 b$ showed the increase in parameter $b^{*}$ when high proportions of chitosan were used in foam formulations. Pranoto et al. (2005) reported that chitosan biodegradable packaging had a yellowish aspect. 


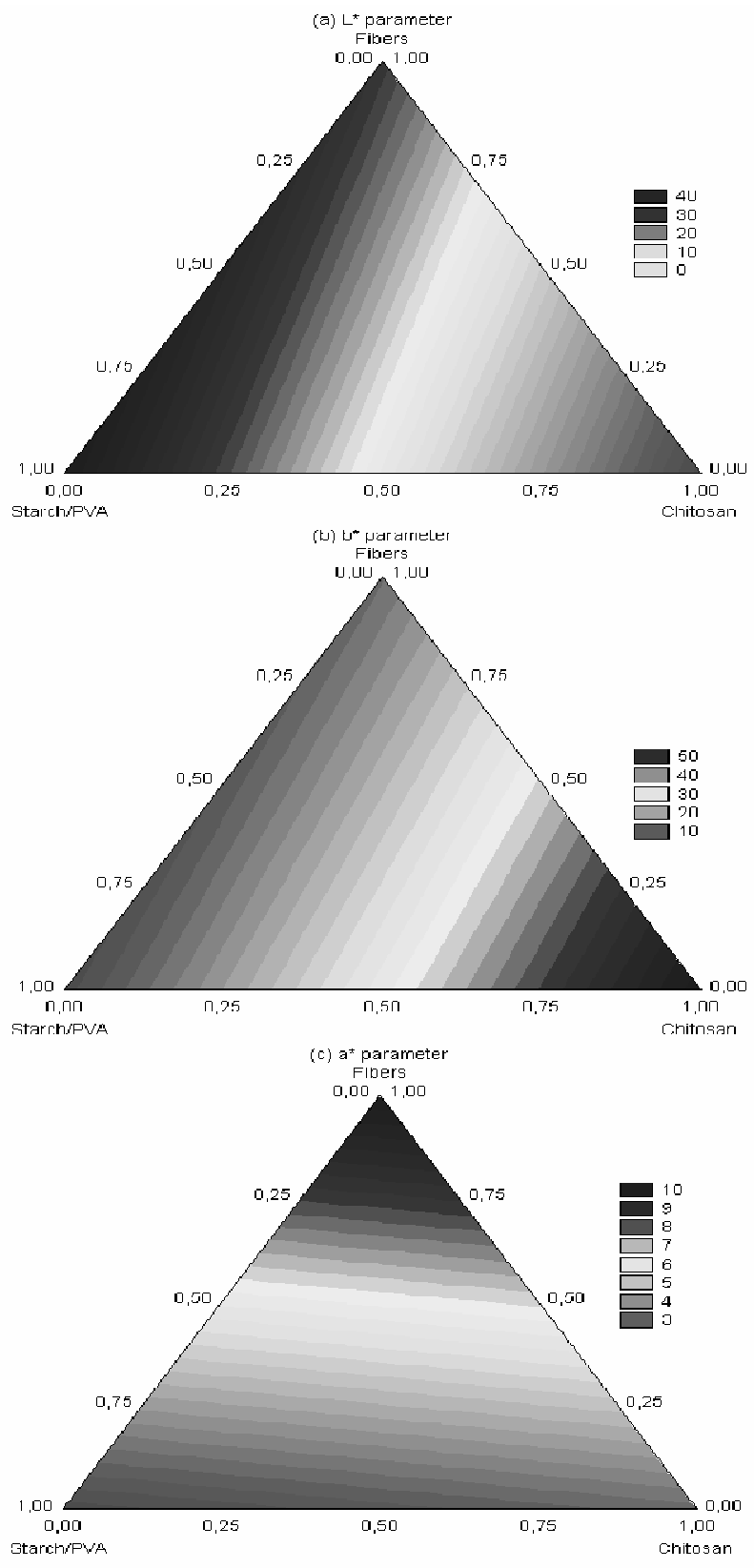

Figure 5 - Contour plot for color parameters of biodegradable foams formulated with starch/PVA, chitosan and sugarcane fibers.

The foam redness observed with the parameter $\mathrm{a}^{*}$ increase was significantly influenced only by the linear effect of fibers proportion $\left(\mathrm{X}_{3}^{\prime}\right)$. When the fibers proportion increased, the redness increased (Fig. 5c). According to Famá et al. (2009), color parameters of starchy biocomposites increased significantly with fiber addition, which limited the use of this reinforcing agent in food applications.

The moisture sorption isotherms of starch foams are shown in Figure 6. The foams presented similar isotherm patterns, and in general, the equilibrium moisture content of the samples increased with the increase in water activity, but the increase in the equilibrium moisture was more pronounced when the samples were stored in $\mathrm{RH}$ above $75 \%$. This behavior was interesting considering that in these materials the main problem was the sensitivity to moisture (Salgado et al., 2008; Mali et al., 2006), and the produced foams in this work were relatively stable to moisture increase with increasing water activity (Relative Humidity /100). 


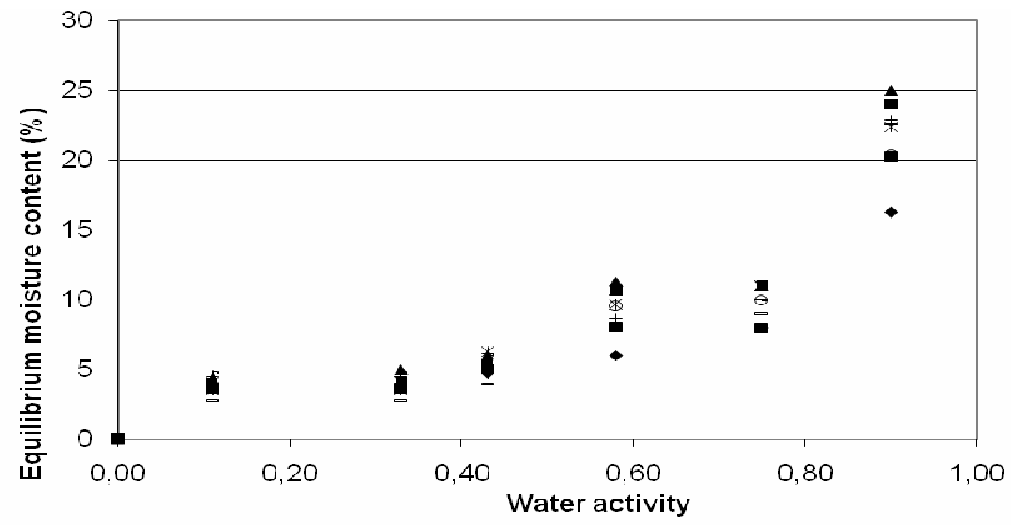

Figure 6 - Sorption isotherms of biodegradable foams formulated as follow: $(\bullet)=100 \%$ starch/PVA; $(\boldsymbol{\square})=98 \%$ starch/PVA and $2 \%$ chitosan; $(\Delta)=70 \% \operatorname{starch} / \mathrm{PVA} ; 2 \%$ chitosan and $28 \%$ fibers; $(\mathbf{x})=72 \%$ starch/PVA and $28 \%$ fibers; $(*)=86 \%$ starch/PVA and $14 \%$ fibers; $(\bullet)=99 \%$ starch/PVA and $1 \%$ chitosan; $(+)=84 \%$ starch/PVA; $2 \%$ chitosan and 14\% fibers; $(-)=71 \%$ starch/PVA; $1 \%$ chitosan and $28 \%$ fibers; $(--)=85 \%$ starch/PVA; $1 \%$ chitosan and $14 \%$ fibers.

\section{CONCLUSIONS}

In this work, biodegradable foams were produced by extrusion of raw materials that were economically important in South America, such as cassava starch and sugarcane bagasse fiber. The introduction of sugarcane fibers could help in improving the properties of starch composites, but in controlled proportions so as not to affect their expansion and color. The studied proportions of chitosan did not improve the properties of the foams. All the formulations were resistant to different environmental conditions until $75 \%$ relative humidity of storage. The produced materials need further development to get the best results of expansion. This study could be the key step in the production of composites at industrial scale.

\section{ACKNOWLEDGEMENTS}

The authors wish to thank the Conselho Nacional de Desenvolvimento Cientifico e Tecnológico (CNPq-No. 577146/2008-4 and 478109/2008-3) of Brazil for the financial support.

\section{REFERENCES}

Bastioli, C.; Bellotti, V.; Del Giudice, L.; Lombi, R.; Rallis A. (1984), Expanded articles of biodegradable plastic materials. US Patent 5.360.830.
Bastioli, C.; Bellotti, V.; Del Tredici, G.; Montino, A.; Ponti, R. (1988), Biodegradable foamed plastic materials. US Patent 5.736.586.

Bhatnagar, S.; Hanna; M.A. (1995), Properties of extruded starch-based plastic foam. Ind. Crop Prod., 4, 71-77.

Carr, L.G.; Parra, D.F.; Ponce, P.; Lugão, A.B.; Buchler. P.M. (2006), Influence of fibers on the mechanical properties of cassava starch foams. J. Polym. Environ., 14, 179-183.

Carvalho, A.J.F.; Zambom, M.D.; Curvelo, A.A.S.; Gandini; A. (2003), Size exclusion chromatography characterization of thermoplastic starch composites 1 . Influence of plasticizer and fiber content. Polym. Degrad. Stabil., 79, 133-138.

Cha, J. Y.; Chung, D.S.; Seib, P.A.; Flores, R. A.; Hanna, M.A. (2001), Physical properties of starch-based foams as affected by extrusion temperature and moisture content. Ind. Crop Prod., 14, 23-30.

Chiellini E.; Cinelli, P.; Ilieva, V.I.; Imam, S.H.; Lawton J.L. (2009), Environmentually compatible foamed articles based on potato starch, corn fiber, and poly (vinyl alcohol). J. Cell Plast., 45, 17-32.

Chiellini, E.; Cinelli, P.; Imam, S.H.; Mao, L. (2001), Composite films based on biorelated agro-industrial waste and poly (vinyl alcohol): preparation and mechanical properties characterization. Biomacromolecules, 2, 1294-1300.

Cinelli, P. Chiellini, E. Lawton, J.W. Imam. S.H. (2006), Foamed articles based on potato starch, corn fibers and poly(vinyl alcohol). Polym. Degrad. Stabil., 91, 11471155.

Cornell, J. A. (1990). Experiments with mixtures: designs, models and the analysis of mixture data. Wiley, London.

Famá, L. ;Gerschenson, L.; Goyanes, S. (2009), Starchvegetable fibre composites to protect food products. Carbohyd. Polym., 75, 230-235. 
Fang, Q.; Hanna, M. (2001), Characterisitics of biodegradable Mater-Bi starch base foams as affected by ingredient formulation. Ind. Crop Prod., 13, 219.

Funabashi, M.; Kunioka, M. (2005), Biodegradable composites of poly (lactic acid) with cellulose fibers polymerized by aluminum triflate. Macromol. Sy., 224, 309-321.

Glenn, G. M.; Orts, W.J.; Nobes; G.A.R. (2001), Starch, fiber and $\mathrm{CaCO}_{3}$ effects on the physical properties of foams made by a baking process. Ind. Crop Prod., 14, 201-212.

Guan, J.; Hanna, M.A. (2004), Functional properties of extruded foams composites of starch acetate and corn cob fiber. Ind. Crop Prod., 19, 255 - 269.

Guan, J.; Hanna, M.A. (2006), Selected morphological and functional properties of extruded acetylated starchcellulose foams. Bioresource Technol., 97, 1716-1726.

Gujska, E.; Khan, K. (1991), Functional properties of extrudates from high starch fractions of navy and pinto beans and corn meal blended with legume igh protein fractions. J. Food Sci., 56, 431-435.

Jin, Z.; Hsieh, F.; Huff; H.E. (1995), Effects of soy fiber, salt, sugar and screw speed on physical properties and microstructure of corn meal extrudate. J. Cereal Sci., 22, 185-194.

Lacourse, N. L.; Altieri P.A. (1989), Biodegradable packaging material and the method of preparation thereof. US Patent, 4.863.655.

Lacourse, N. L.; Altieri P.A. (1991), Biodegradable shaped products and the method of preparation thereof. US Patent, 5.043.196.

Lawton, J.W.; Shogren, R.L.; Tiefenbacher K.F. (2005), Aspen fiber addition improves the mechanical properties of baked cornstarch foams. Ind. Crop Prod., 19, 41-48.

Lee S.Y.; Eskridge, K.M.; Koh, W.Y.; Hanna M.A. (2009). Evaluation of ingredient effects on extruded starch-based foams using a supersaturated split-plot design. Ind. Crop Prod., 29, 427-436.

Lui, W.B.; Peng, J. (2005), Effects of die shapes and additives on the physical and mechanical properties, and cellular structure of biodegradable cushioning extruded foams. J Cell Plast., 41, 437-455.

Mali, S.; Grossmann, M.V.E.; García, M.A.; Martino, M.M.; Zaritzky N.E. (2006), Effects of controlled storage on thermal, mechanical and barrier properties of plasticized films from different starch sources. J. Food Eng., 55, 453- 460.

Miladinov, V.D.; Hanna. M.A. (2001), Temperatures and ethanol effects on the properties of extruded modified starches. Ind. Crop Prod., 13, 21-28.

Moraru, C.I.; Kokini, J.L. (2003), Nucleation and expansion during extrusion and microwave heating of cereal foods. Compr. Rev. Food Sci. F., 2, 147-165.

Nakamatsu, J.; Torres, F.G.; Troncoso, O. P.; Min-Lin, Y.; A.R. Boccaccini (2006), Processing and characterization of porous structures from chitosan and starch for tissue engineering scaffolds. Biomacromolecules, 7, 3345 3355 .

Pranoto, Y.; Rakshit, S.K.; Salokhe V.M. (2005), Enhancing antimicrobial activity of chitosan films by incorporating garlic oil, potassium sorbate and nisin. LWT - Food Sci. Technol., 38, 859-865.

Preechawong, D.; Peesan, M.; Supaphol, P.; Rujiravanit, R. (2004), Characteiztion of starch/poly ( $\varepsilon$-caprolactone) hydrid foams. Polym. Test., 23, 651-657.

Rhee, K.S.; Cho, S.H.; Pradahn, A.M. (1999), Expanded extrudates from corn starch-lamb blends: process optimization using response surface methodology. Meat Sci., 52, 127-134.

Rockland, L. B. (1960), Saturated salt solutions for static control of relative humidity between $5^{\circ}$ and $4^{\circ} \mathrm{C}$. Anal. Chem., 32, 1375-1376.

Ruggiero, R.; Machado, A.E.H.; Hoareau, W.; Gardrat, C.; Nourmamode, A.; Grelier, S.; Castellan, A. (2006), Photodegradation of sugarcane bagasse fibers: influence of acetylation or grafting UV-absorber and/or hindered nitroxide radical on their photostability. J. Braz. Chem. Soc., 17, 763-770.

Salgado, P.R.; Schmidt, V.C.R.; Ortiz, S.E.M.; Mauri, A.N.; Laurindo J.B. (2008), Biodegradable foams based on cassava starch, sunflower proteins and cellulose fibers obtained by a baking process. J. Food Eng., 85, $435-443$.

Shey, J.; Imam, S.H.; Glenn, G.M.; Orts. W.J. (2006), Properties of baked starch foam with natural rubber latex. Ind. Crop Prod., 24, 34-40.

Shogren, R.L.; Lawton, J.W. (1998), Enhanced Water Resistance of Starch-based Materials, U.S. Patent No. 5.756.194.

Shogren, R.L.; Lawton, J.W. (2002), Baked starch foams: starch modifications and additives improve process parameters, structure and properties. Ind. Crop Prod., 16, 69-79.

Shogren, R.L.; Lawton, J.W.; Teifenbacher, K.F.; Chen, L. (1998), Starch-poly (vinyl alcohol) foamed articles prepared by a baking process. J. Appl. Polym. Sci., 68, 2129-2140.

Soykeabkaew, N.; Supaphol P.; Rujiravanit, R. (2004), Preparation and characterization of jute and flax reinforced starch-based composite foams. Carbohyd. Polym., 58, 53-59.

Tatarka, P.D.; Cunningham, R.L. (1998), Propertied of protective loose-fill foams. J. Appl. Polym. Sci., 67, 1157-1176.

Wang, X.; Chung, Y. S.; Lyoo, W. S.; Min, B. G. (2006), Preparation and properties of chitosan/poly(vinyl alcohol) blend foams for copper adsorption. Polym. Int., 55, 1230-1235.

Willett J.L.; Shogren, R.L. (2002), Processing and properties of extruded starch/polymer foams. Polymer, 43, 5935-5947.

Xu, Y.; Hanna M.A. (2005), Preparation and properties of biodegradable foams from starch acetate and poly(tetramethylene adipate-co-terephthalate). Carbohyd. Polym., 59, 521-529.

Received: May 14, 2010; Revised: October 22, 2010; Accepted: July 01, 2011. 